KARLA GAŠPARIĆ

Varaždin

gasparickarla@gmail.com

IVA GREGUREC

Fakultet organizacije i informatike, Varaždin

iva.gregurec@foi.unizg.hr

DAMIR DOBRINIĆ

Fakultet organizacije i informatike, Varaždin

ddobrinic@foi.unizg.hr
Primljeno: 29. 12. 2020.

Prihvaćeno: 25. 02. 2021.

DOI: $10.21857 / y 54 j o f k 0 d m$

\title{
PRIMJENA OPTIMIZACIJE U ONLINE TRGOVANJU - PRIMJER PODUZEĆA U SJEVERNOJ HRVATSKOJ
}

Internet se u ranijim fazama svog nastanka koristio u specifične svrhe poput razmjene informacija unutar velikih poduzeća ili državnih ustanova. Proširenjem dostupnosti krajnjim korisnicima povećavao se i broj informacija koje su se na internetu mogle pronaći. Kako bi korisnici mogli brzo i jednostavno pronaći za njih relevantnu informaciju koriste se tražilice. Korištenjem tražilica u prvi plan vlasnici web stranica stavljaju optimizaciju za tražilice, što je ujedno i fokus ovog rada.

Analizom dostupnih sekundarnih izvora podataka postavljena je teorijska osnova pojma i uloge optimizacije, kao i osnovnih dijelova i tipova optimizacije za tražilice. U sklopu empirijskog istraživanja stvoren je anketni upitnik pomoću kojeg je provedeno kvantitativno istraživanje na mikro i malim poduzećima u sjevernoj Hrvatskoj. Anketni upitnik odaslan na e-poštu stručnjaka (za digitalni marketing ili marketing općenito) 52 poduzeća, od čega je 10 stručnjaka u potpunosti odgovorilo na sva pitanja te je na njihovim odgovorima provedena statistička analiza. Cilj je rada spoznati razinu korištenja optimizacije za tražilice kod poduzeća koja posluju na sjeveru Hrvatske uključujući i upoznatost sa samim pojmom optimizacije.

Temeljem dobivenih rezultata može se zaključiti kako su poduzeća većinom upoznata sa pojmom optimizacije, te istu koriste u svom poslovanju. No, iako koriste brojne faktore koji su važni za povećanje pozicije na tražilicama ipak svjesnost prednosti i uloge optimizacije u poslovanju još uvijek nije u potpunosti formirana.

Ključne riječi: digitalni marketing; online trgovanje; SEM; PPC; SEO; sjeverna Hrvatska. 


\section{UVOD}

Optimizacija (engl. Search Engine Optimization - SEO) jedan je od oblika marketinga na tražilicama (engl. Search Engine Marketing - SEM). Kao element promotivnog spleta internetskog marketinga zadužena je za promociju web stranica povećanjem njihove vidljivosti u rezultatima pretraživanja na tražilicama. Prikazivanje web stranice na što višim pozicijama u rezultatima pretraživanja cilj je marketinga na tražilicama koji upravo optimizaciju web stranica koristi za ostvarivanjem tog cilja. Za poduzeće je to jedan od osnovnih načina povećavanja vidljivosti njegove web stranice. ${ }^{1}$ Metoda povećanja vidljivosti dijeli se na dvije kategorije: optimizaciju (SEO) i plaćeni oglasi na tražilicama ili plaćeno pretraživanje (engl. Pay per Click). ${ }^{2}$ Kako bi se web stranica prilikom pretraživanja na tražilicama pozicionirala na što višem mjestu provodi se njezina optimizacija (SEO). U pravilu se radi o primjeni različitih tehnika s ciljem povećanja organskog promet prema web mjestu. Dok s druge strane plaćeno pretraživanje, kao što i sam naziv govori, predstavlja oglašavanje koje se plaća, ${ }^{3}$ tj. plaćanje za prikazivanje web stranice na tražilicama prema određenim ključnim riječima. ${ }^{4}$ Obje kategorije povećanja vidljivosti web mjesta imaju zajednički cilj, privući što veći broj korisnika (potencijalnih kupaca), tj. povećati promet prema određenoj web stranici. $^{5}$

1 W. T. KRITZINGER, M. WEIDEMAN, "Search Engine Optimization and Pey-Per-Click Marketing Strategies", Journal of Organizational Computing and Electornic Commerce, 2013., Vol. 23, 273-286., 273.

2 Aleksandra KRAJNOVIĆ, Dominik SIKIRIĆ, Monika HORDOV, Digitalni marketing - nova era tržišne omunikacije, Sveučilište u Zadru, Zadar, 2019., 93.

3 Chen-Yuan CHEN, Bih-Yaw SHIH, Zih-Siang CHEN, Tsung-Hao CHEN, "The exploration of internet marketing strategy by search engine optimization: A critical review and comparison", African Journal of Business Management, 2011., Vol. 5, No. 12, 4644-4649., 4645.

4 https://tilio.hr/google-adwords-oglasi/ (preuzeto 10. 06. 2020.)

5 https://kuhada.com/blog-novosti-i-najave/47-vijesti/341-razlika-izmedju-sem-i-seo.html (preuzeto 27. 05. 2020.). 


\section{OPTIMIZACIJA WEB STRANICA}

U nastavku rada daje se teorijski okvir optimizacije (SEO) te prikaz tri dijela napredne optimizacije (on-page optimizacija, off-page optimizacija te tehnički SEO). Nakon razrađenih dijelova optimizacije pružit će se uvid i u dva glavna tipa optimizacije (white hat i black hat SEO) te u sam proces optimizacije.

Optimizacija (SEO) predstavlja proces optimizacije web stranice za tražilice. Poduzeće vlastitu web stranicu pomoću raznih metoda i alata optimizira (usklađuje, uređuje) kako bi se pojavila na što višem mjestu u rezultatima pretraživanja. Radi se o skupu metoda čiji je cilj povećati promet određenog web mjesta, a time i samu kvalitetu istog. U pravilu je optimizacija usmjerena na internet korisnike jer su oni ti koji upisuju željeni pojam u tražilicu. ${ }^{8}$ Međutim, i samo poduzeće je direktno zainteresirano da njegova web stranica bude na najvišoj poziciji na tražilici za traženi pojam kako bi korisnici najprije kliknuli na nju, a ne na konkurentnu web stranicu. ${ }^{10}$

\subsection{On-Page optimizacija}

Nesumnjivo je da optimizacija web stranice predstavlja prioritet za poduzeće koje želi uspješno poslovati i u digitalnom okruženju. U okviru on-page optimizacije, koja se često naziva i unutarnjom optimizacijom, pažnja se posvećuje svim elementima web stranice a naročito njezinom vizualnom izgledu, sadržaju, odabiru ključnih riječi, dužini ključnih riječi, naslovu, naslovnim oznakama, strukturi poveznica i sl.1. On-page optimizacija je uobičajena optimizacija web stranica koja se provodi s ciljem ostvarivanja što većeg prometa na tražilicama. ${ }^{12}$

6 Ayush JAIN, „The Role and Importance of Search Engine and Search Engine Optimization“, International Journal of Emerging Trends and Technology in Computer Science, 2013., Vol. 2, No. 3, 99-102., 100.

7 Jakub ZILINCAN, „Search engine optimization“, CBU International Conference of Innovation, Technology Transfer and Education, 2015., 506-510., 506.

8 https://www.jasnoiglasno.com/sto-je-seo-i-zasto-je-bitan-3938/(preuzeto 01. 06. 2020.)

9 Ron BERMAN, Zsolt KATONA, "The Role of Search Engine Optimization in Search Marketing“, Marketing Science, 2013., Vol. 32, No. 4, 644-651., 644.

$10 \mathrm{https}: / /$ www.jasnoiglasno.com/sto-je-seo-i-zasto-je-bitan-3938/(preuzeto 01. 06. 2020.)

11 Eric ENGE, Stephan SPENCER, Rand FISHKIN, Jessie. C. STRICCHIOLA, "The Art of SEO: Mastering Search Engine Optimization“ (1st edition), O’Reilly Media, Inc., Sebastopol, 2009., 135.

$12 \mathrm{https}: / /$ neomedia.hr/napredna-optimizacija-za-trazilice-on-page-seo/ (preuzeto 02.06. 2020.). 
Najbitniji faktori kod provođenja on-page optimizaciji su: ${ }^{13}$

- $\quad$ Sadržaj stranice - sadržaj predstavlja ono čime se poduzeće bavi i ono što je korisnik došao vidjeti na web stranicu. Stoga je sadržaj izuzetno važan u pogledu rezultata pretraživanja. „Sadržaj stranice je najvažniji element web stranice zato što poboljšava rang kod tražilica. ${ }^{14}$ Kod sadržaja je najvažnije korištenje ključnih riječi, ali i gustoća njihova korištenja.

- Naslovne oznake (engl. title tag) - također važan faktor kod on-page optimizacije jer se jedinstvenim i točnim nazivima stranica tražilicama i korisnicima olakšava pretraživanje istih. U tom kontekstu je nužno koristiti jedinstvene naslovne oznake za svaku stranicu te koristiti kratke i opisne nazive (važnost korištenja jasnih, razumljivih i kratkih ključnih riječi). U svrhu dodatnog olakšavanja pretraživanja na tražilicama koristi se i opisni meta tag (engl. meta description tag) kojim se detaljnije opisuje web sjedište. ${ }^{15}$

URL-ovi (engl. Uniform Resorce Locator) ili usklađeni lokator sadržaja predstavlja web adresu lokacije određene web stranice. To je zapravo poveznica na bilo koju stranicu i nalazi se na gornjoj traci u tražilicama. Adrese web stranica trebaju sadržavati određene riječi prema kojima će tražilica rangirati web stranicu. Određivanja URL-a podliježe i određenim pravilima njihovog oblikovanja i uređivanja.

Navigacija - tražilice navigaciju smatraju bitnim faktorom jer je izražen $i$ njihov interes da se potencijalni korisnici / kupci lako snalaze na stranici. Nužno je kreirati logičan izbornik koji će omogućiti lako snalaženje na web stranici. Važnost ugodnog i jednostavnog pretraživanja web stranice vodi ka većoj prodaji, tj. većoj konverziji.

Vizuali (vizualni identitet) - predstavljaju fotografije ili neke druge grafičke prikaze unutar web stranice. Fotografije, grafički prikazi i video mogu utjecati na poziciju web stranice te je nužno provesti njihovu optimizaciju.

$13 \mathrm{https}: / / \mathrm{moz} . c 0 m /$ learn/seo/on-page-factors (preuzeto 02. 06. 2020.).

14 Jerry L. LEDFORD, „Search Engine Optimization Bible“ (2nd edition), Wiley Publishing, Inc. Indiapolis, 2008., 11.

15 E. ENGE, S. SPENCER, R. FISHKIN, J.C. STRICCHIOLA, „,The Art of SEO: Mastering Search Engine Optimization", 38. 
Optimizacija vizuala odnosi se na povezivanje slike s tekstom kako bi tražilice mogle prepoznati ono što se na slici nalazi. Trenutni tehnološki razvoj tražilicama ne omogućava čitanje i analiziranje samih slika (osim sustava za prepoznavanje lica i čitanje teksta sa slika, što se uglavnom ne koristi). Postoje dva elementa preko kojih tražilice učitavaju slike, a to su alt tag / oznake i naziv (engl. filename) slike.

Primjer: poduzeće prodaje posuđe od porculana. Na stranici je važno da prvotno postoji kategorija posuđe što je jedna ključna riječ, a zatim postoji potkategorija posuđe od porculana gdje porculan predstavlja drugu ključnu riječ. Prema navedenom primjeru Google će moći rangirati ovu web stranicu na više mjesto $u$ tražilici (ako su i ostali faktori on-page optimizacije zadovoljavajući) kada kupac pretražuje posuđe od porculana. ${ }^{17}$

\subsection{Off-Page optimizacija}

Za razliku od on-page optimizacije, off-page optimizacija se ne odvija na samoj web stranici, nego izvan nje zbog čega se i naziva vanjskom optimizacijom. Ona se obavlja nakon on-page optimizacije sa svrhom boljeg rangiranja kod tražilica. Bolje rangiranje, tj. bolja vidljivost web stranice osigurava se kroz izgradnju poveznica (linkova) koje generiraju posjete sa srodnih web stranica. Elementi koji su važni kod vanjske optimizacije su: vanjske poveznice (engl. backlinks), izgradnja povjerenja i autoriteta te tekst koji upućuje na drugu stranicu (engl. anchor text).

Vanjska poveznica ili backlink omogućava povezivanje srodnih web stranica. Korisnici ili potencijalni kupci klikom na poveznicu dolaze na drugu srodnu web stranicu. Za poduzeće i vidljivost njegove web stranice bitno je da tih poveznica ima što je moguće više. Veći promet prema određenoj stranici signalizira tražilicama da se radi o zanimljivom sadržaju te se stranica bolje rangira. Bitno je da se poveznice nalaze na stranicama koje su relevantne tržišnoj niši stranice na koju poveznica upućuje. ${ }^{18}$ Također je za rangiranje stranice bitna reputacija i autoritet web stranica na kojima se poveznice nalaze. Stoga je važno ciljati na stranice koje

16 E. ENGE, S. SPENCER, R. FISHKIN, J. C. STRICCHIOLA, Isto 371.

17 Karla GAŠPARIĆ, Uloga optimizacije u online trgovanju - diplomski rad, Fakultet organizacije i informatike, Varaždin, rujan 2020., 17.

18 Ghulam Ali RAHU, Mansoor Hyder DEPAR, Sher Muhammad DAUDPOTO, Mir Sajjad Hussain TALPUR, Muhammad Malook RIND, Gordhan DAS, „Extending off-page search engine optimization (SEO) techniques based od google SEO techniques model", Sci.Int. (Lahore), 2016., Vol. 28, No. 5, 4377-4384., 4379. 
dobro kotiraju i imaju povjerenje od strane tražilica. ${ }^{19}$ Ne treba zanemariti niti konzistentnost backlinkova koja se odnosi na njihovu postojanost, tj. da se ne mijenjaju često. Njihovim čestim promjenama dolazi do neprepoznavanja od strane tražilica te padom ranga i prometa. ${ }^{20}$ Neupitno je da je web stranica koja ima puno backlinkova bolja, učinkovitija i ima više mogućnosti za napredak i veću pozicioniranost na tražilici. ${ }^{21}$

\subsection{Tehnička optimizacija}

Ovaj dio optimizacije se odnosi na tehničke faktore koji utječu na rad web stranice, odnosno konkretnije na brzinu stranice i mogućnost da tražilice pravilno indeksiraju stranicu. Postoje mnogobrojni faktori za optimizaciju koje tražilice koriste, a neki od njih su: indeksiranje stranice, brzina web stranice, hosting web stranice, linkovi koji ne rade te brojni drugi. ${ }^{22}$ Svi od navedenih faktora su bitni i značajni za optimizaciju web stranice. Budući da svaki faktor može prilikom rada uzrokovati i određene probleme bitno ih je dobro poznavati kako bi se eventualni problemi mogli i efikasno rješavati. Najbolji učinak faktori imaju ako su povezani i ako se nadopunjuju.

Primjer: poduzeće se tek upoznalo s optimizacijom stranice za tražilice te je odlučilo primijeniti savjete stručnjaka kako bi bili što uspješniji. Prilikom optimizacije stranice, poduzeće zamjećuje veliki broj faktora koji su relevantni kako bi optimizacija za tražilice bila uspješna. Tijekom vremena, nakon početnih pogrešaka poput linkova koji nisu radili, poduzeće je uspješno rangirano od strane Google-a u rezultatima pretraživanja, ali stručnjaci u poduzeću neprekidno usavršavaju svoja znanja kako bi poduzeće raslo te kako bi se izbjegle moguće pogreške. ${ }^{23}$

19 Jai MANRAL, Mohammed Alamgir HOSSAIN, „An Inovative Approach for online Meta Search Engine Optimization", The 6th Conference on Software, Knowledge, Information Management Application, Chengdu, China, 2012., 1-7., 3.

20 Mayank Kumar MITTAL, Neha KIRAR, Jasraj MEENA, „Implementation of search engine optimization-Through white hat techniques", International Conference on Advances in Computing, Communication Control and Networking, 2018., 674-678., 677.

21 Vikas M. PATIL, Amruta V. PATIL, „SEO: On-Page + Off-Page Analysis“, International Conference on Information, Communication, Engineering and Technology (ICICET), Zeal College of Engineering and Research, Narhe, Pune, India, 2018., 1-3., 2.

22 https://neomedia.hr/napredna-optimizacija-za-trazilice-tehnicki-seo (preuzeto 03. 06. 2020.).

${ }^{23}$ K. GAŠPARIĆ, „Uloga optimizacije u online trgovanju“, 22. 
Potrebno je istaknuti kako sva tri dijela optimizacije (on-page, off-page i tehnički SEO) moraju biti ujednačena te in se mora međusobno povezivati ako poduzeće želi imati kvalitetnu web stranicu koju će tražilica visoko rangirati. ${ }^{24}$

\subsection{Tipovi optimizacije za web tražilice}

Nakon definiranja osnovnih dijelova optimizacije i njihovih uloga važno je nadovezati se i tipovima optimizacije. Prema literaturi to su white hat i black hat optimizacija.

White hat optimizacija podrazumijeva kvalitetan i dobar dizajn web stranice prema određenim smjernicama koje tražilice zahtijevaju. Krajnji cilj ovog tipa optimizacije je kroz stvaranje sadržaja za posjetitelje olakšati rad tražilicama. Ako je tražilica (uglavnom se radi o Googlovoj) postavila pravila za stvaranje sadržaja stručnjaci za izradu i ažuriranje web stranica moraju ta pravila i slijediti. Ta se pravila najčešće zovu i algoritmima prema kojima tražilice rangiraju web stranice..$^{25}$ Velika prednost korištenja ovog tipa optimizacije je da su rezultati dugoročni čak i ako se nakratko obustavi rad na web stranici. ${ }^{26}$ Druga bitna prednost je i da su male šanse da će web stranica biti „kažnjena“ od strane tražilica. ${ }^{27}$ Podrazumijeva se da poduzeće mora kontinuirano nadopunjavati svoju web stranicu novim sadržajima ako želi da mu web stranica bude na vrhu rezultata pretraživanja. Osim unapređivanja stranice bitno se usredotočiti i na dodatno obučavanje zaposlenika koji rade na održavanju web stranica. Dodatna znanja i vještine zaposlenih svakako će doprinijeti konkurentnosti i dugoročnom uspjehu poduzeća. Ovaj tip optimizacije se smatra dobrom metodom budući da se poduzeća prilikom primjene pridržavaju određenih pravila koja su tražilice odredile. ${ }^{28}$ Neka od bitnijih pravila se odnose na: naslov, opis web stranice, ključne riječi, ponavljanje ključnih riječi u sadržaju (tekstu) web stranice, zatim pojedine ključne riječi, broj linkova (poveznica), sitemap ili karta stranice te URL adresa stranice. Vidljivo je da postoji čitav niz detalja na koje se treba fokusirati prilikom optimizacije. Uvažavanje svakog detalja na stranici znači prednost kod rangiranja, veći promet a time i bolje poslovanje. Ovaj tip optimizacije zahtjeva više truda i vremena, ali je krajnji rezultat sigurniji za poduzeće..$^{29}$

24 J. MANRAL, M.A. HOSSAIN, n. dj., 3.

25 A. JAIN, n.dj., 101.

26 https://digitalcircleweb.com/seo-zurnal/seo-strategije-black-hat-white-hat-gray-hat-i-asshat/ (preuzeto 08.06.2020.)

27 M. K. MITTAL, N. KIRAR, J. MEENA, n. dj., 677.

28 Ross A. MALAGA, "Search Engine Optimization-Black and White Hat Approaches", Advances in Computers, 2010., Vol. 78., 1-39., 18.

29 http://www.webtech.com.hr/seo.php (preuzeto 08. 06. 2020.). 
S druge strane, black hat optimizacija nije dobra za poduzeće jer je kratkoročnog vijeka te njenom primjenom poduzeće neće postići one rezultate koje priželjkuje. Ovaj tip optimizacije nije odobren od strane tražilice te postoji velika mogućnost da web stranica bude "kažnjena" od strane tražilice ako ju poduzeće primjenjuje. $^{30}$

Učinak ovog tipa optimizacije je kratkoročan za razliku od white hat tipa optimizacije. Kazna za njeno korištenje je spuštanje web stranice u rezultatima pretraživanja na tražilicama ili njezino brisanje u potpunosti. ${ }^{31}$ Black hat tip optimizacije se usmjerava na izbjegavanje pravila koja tražilica propisuje. ${ }^{32}$ Najčešći razlog zašto bi poduzeće uopće koristilo ovaj tip optimizacije je taj da žele u što kraćem roku imati što bolju poziciju na tražilici. ${ }^{33}$ Jedan od primjera korištenja ovog tipa optimizacije je korištenje teksta koji je skriven na način da se koristi ista boja fonta i pozadine. Primjer može biti i cloaking ili prikazivanje različitog sadržaja korisnicima i tražilicama. Važno je istaknuti kako ovaj tip optimizacije nije isto što i hakiranje iako se često pojmovi poistovjećuju. To je samo način optimizacije u kojem se izbjegavaju pravila koja su tražilice nametnule. ${ }^{34}$

\section{PROCES OPTIMIZACIJE}

Kada se govori o procesu optimizacije otvara se veliki broj pitanja čiji odgovori pomažu stručnjacima za optimizaciju da ju provedu na najbolji način. Što je najbolje i što najviše odgovara svakom pojedinom poduzeću najbitnije je pitanje. Kako bi se otkrili odgovori na neka od tih pitanja važno je razumjeti što sve proces optimizacije mora uključivati. Svakako se radi o on-page optimizaciji kao i primjeni white hat tipa optimizacije. Dakle, sam proces optimizacije web stranice obuhvaća sljedeće: ${ }^{35}$

R.A. MALAGA, n.dj., 36.

31 A. JAIN, n. dj., 101.

32 https://digitalcircleweb.com/seo-zurnal/seo-strategije-black-hat-white-hat-gray-hat-i-asshat/ (preuzeto 08. 06. 2020.).

33 M. K. MITTAL, N. KIRAR, J. MEENA, n. dj., 19.

34 K. GAŠPARIĆ, „Uloga optimizacije u online trgovanju“, 25.

35 https://marker.hr/blog/kako-povecati-prodaju-putem-ppc-oglasa-149/ (preuzeto 02.06.2020.). 
- Istraživati ključne riječi - odabir pravilnih i adekvatnih ključnih riječi je važno jer se upravo time postiže prednost kod rangiranja na tražilicama. Istraživanje se vrši putem raznih alata pomoću kojih se prati što su kupci najviše pretraživali.

- Iskoristiti prednost dugih ključnih riječi - ovaj korak predstavlja detaljnu specifikaciju ključnih riječi, odnosno riječi koje se odnose na određeno poduzeće.

- Adekvatno strukturirati web stranicu - bilo da je riječ o slikama, linkovima ili povezanosti stranice, važno je da je ona pravilno strukturirana kako bi se kupci lakše mogli na njoj snalaziti. Važno je istaknuti i proizvode kao i pitanja koja su najčešća kod pretraživanja.

- Dodavati nove sadržaje stranici - kontinuirano poboljšavanje i osvježavanje stranice je bitno kako se kupci ne bi zasitili stranice, odnosno poduzeća. Novi sadržaji nisu važni samo za kupce već i za tražilice, u slučaju da se web stranica ne osvježava tražilica može smatrati da je ona neaktivna i neće je više rangirati.

- Dodavati sadržaj koji odgovara na pitanja kupaca - kupci očekuju brze odgovore na svoja pitanja kroz bilo koji medij (e-mail, poruke na društvenim mrežama i sl.).

- Pisati za ljude, a optimizirati za strojeve - poduzeće mora balansirati između tražilica i korisnika. S jedne strane, mora osigurati zanimljiv sadržaj na stranici, a s druge, kako bi postiglo najbolje rangiranje od strane tražilice mora raditi na kvalitetno strukturiranim naslovima i opisima članaka. Na taj se način tražilicama olakšava prepoznavanje poduzeća kao izuzetno kvalitetnog i adekvatnog.

- Pisati sinonime i izvedenice za privlačenje pozornosti - kod procesa optimizacije je također važno da poduzeće ne inzistira na nekoliko ključnih riječi, već da koristi sinonime i izvedenice koje najbolje opisuju djelatnost samog poduzeća. Kao što je već ranije spomenuto važna je kvaliteta ključnih riječi, a ne njihov broj.

- Pisati korisne i kvalitetne članke - pisanje kvalitetnih članaka se može dugoročno isplatiti poduzeću. Poduzeće koje piše detaljne članke ima velike šanse na samom vrhu kod rangiranja na tražilicama.

- Graditi interne - interni na svakom od proizvoda mogu doprinijeti boljem rangiranju stranice.

- Strukturirati naslove, URL-ove i slično - na ove detalje tražilice obraćaju veliku pozornost. Ako su naslovi „pametno“ strukturirani veća je šansa za visoku poziciju u rezultatima pretraživanja. 
- Iskoristiti društvene mreže - svako poduzeće koje prodaje preko internetske trgovine trebalo bi imati profil na društvenim mrežama. Ako poduzeće ima stranicu na društvenim mrežama veća je šansa da će tamo podijeljen sadržaj kupci dijeliti sa svojim prijateljima, što izravno vodi boljem rangiranju stranice.

- Pratiti brzinu stranice - brzina otvaranja stranice utječe na to hoće li kupci ostati na stranici ili ne. Ako se svaki pojedini dio stranice predugo otvara ili se uopće ne može otvoriti, veća je vjerojatnost da će kupac otići na konkurentnu stranicu.

- Pratiti brzinu otvaranja stranice - kao i prethodni korak, praćenje brzine otvaranja stranice je važno jer je dokazano kako kupci već nakon 2 sekunde čekanja odustaju i odlaze na drugo web mjesto.

- Pratiti broj posjetitelja - praćenje broja posjetitelja daje poduzeću uvid u to koliko je stranica kvalitetna i dobro strukturirana. Ako stranica nema veliki ili rastući broj svakodnevnih posjetitelja to može biti znak da nešto treba promijeniti i poboljšati.

- Odrediti prosječno vrijeme zadržavanja kupaca na stranici - ako kupac klikne na link stranice i na njoj se zadrži dvije do tri sekunde vrlo je vjerojatno da je slučajno kliknuo na link i nema namjeru kupovati. Osim zadržavanja na stranici može se pratiti i koje je proizvode kupac redom pretraživao.

- Pratiti broj obavljenih kupnji - kada kupac stigne na stranicu, ne mora značiti da će on nešto i kupiti, stoga je važno pratiti broj obavljenih kupnji kako bi poduzeće bilo sigurno da je na pravom putu optimizacije.

- Pratiti bounce rate postotak - ovaj postotak zapravo određuje koliki broj posjetitelja je otišao sa stranice. Ako je postotak veliki poduzeće nešto radi pogrešno.

Potrebno je istaknuti kako su navedeni koraci povezani i poduzeće ih sve mora uzeti u obzir prilikom optimizacije. Njihova kombinacija i proučavanje daju veću šansu za visoko rangiranje od strane tražilica. U slučaju kada se poduzeće odluči na proces optimizacije on mora biti neprekidan i kao takav tražiTI stalna ulaganja. Ulaganje intelektualnog znanja je na prvom mjestu jer optimizacija u svojoj biti predstavlja besplatan način dolaska na najvišu poziciju na tražilici, a za to su potrebni stručni zaposlenici. 


\section{ISTRAŽIVANJE}

Cilj istraživanja u ovom radu je spoznati razinu korištenja optimizacije za tražilice kod poduzeća sjeverne Hrvatske. S tom svrhom provedeno je i empirijsko istraživanje koje se opisuje u nastavku. Anketni upitnik, kao instrument prikupljanja primarnih podataka, poslan je na adrese elektroničke pošte 52 poduzeća u sjevernoj Hrvatskoj. Temeljem izrađene liste poduzeća elektronička pošta je adresirana na stručnjake za digitalni marketing ili marketing općenito (ovisno o organizacijskoj strukturi poduzeća). Ovakav pristup slanja anketnog upitnika određuje da se radi o namjernom uzorku, uzorku stručnjaka. Od svih kontaktiranih poduzeća samo deset stručnjaka (19,23\% odgovora) u potpunosti je odgovorilo na sva pitanja postavljena u anketnom upitniku.

Anketa je bila anonimna te se u rezultatima istraživanja ne prikazuju nazivi i područje poslovanja poduzeća iz uzorka. Anketiranje je trajalo od 26. srpnja do 20. kolovoza 2020., a anketni upitnici su poslani na e-adrese svih 52 poduzeća u tri navrata. Neka od poduzeća iz uzorka ne bave se online trgovinom, ali na svojim web stranicama imaju istaknute proizvode ili usluge koje kupci mogu vidjeti te obaviti kupnju ili rezervirati proizvod/uslugu fizički. Ta su poduzeća izjavila kako svakako planiraju u skoroj budućnosti uključiti u svoje poslovanje i online trgovinu, na što ih je dodatno potaknula i COVID-19 pandemija.

Pitanja u anketi bila su podijeljena u dvije grupe. Prva grupa odnosila se na općenite podatke o poduzeću dok su pitanja u drugoj grupi bila vezana za konkretno korištenje i primjenu optimizacije web stranica. Uslijedilo je pitanje koliko dugo posjeduju web stranicu. Budući da je na anketu odgovorilo deset poduzeća i da su neka mlada dok druga posluju dugi niz godina razumljivo je da posjedovanje web stranice varira od 4 mjeseca pa sve do 16 godina. Sljedeće pitanje odnosilo se na mišljenje o važnosti posjedovanja web stranice te njezin utjecaj na ukupni financijski rezultat poduzeća. Svih deset poduzeća je odgovorilo kako je posjedovanje web stranice bitno utjecalo na njihov ukupni financijski rezultat neovisno o tome prodaju li putem web stranice ili ne. Poduzeća koja nemaju online prodaju navode kako web stranicu koriste za informiranje i komunikaciju sa svojim kupcima. Objavom adrese e-pošte, broja telefona i fax uređaja na web stranicama kupcima se otvaraju kanali izravnog kontakta s poduzećem. Na pitanje o povećanju online prodaje uslijed korištenja web stranice poduzeća koja imaju online prodaju (njih 6) navode kako je povećanje u online prodaji prisutno. Nadalje, na pitanje o povećanju posjećenosti web stranice u proteklom razdoblju, 
bez da se radi o izravnoj online prodaji, osam od deset poduzeća odgovorilo je kako se posjećenost povećala. Ujedno naglašavaju kako im je posjedovanje web stranice povećalo broj upita i narudžbi te će svakako u budućnosti veću pažnju posvetiti upravo online trgovanju. Jedno od sljedećih pitanja bilo je vezano uz utjecaj jedinstvenog digitalnog tržišta EU na povećanje prodaje njihovog poduzeća. Iznenađujuće, samo su dva poduzeća navela kako im je ono utjecalo na povećanje prodaje. Oba poduzeća su kao razlog povećanja prodaje navela da su upravo zbog jedinstvenog digitalnog tržišta proširili svoju online prodaju na druge države Europske unije. To im omogućuje da aktivno prate promjene u digitalnom europskom i svjetskom okruženju te da osiguraju konkurentnost i na globalnom tržištu. Od stručnjaka koji su sudjelovali u istraživanju zatraženo je mišljenje o tome koji su to elementi dobre web stranice na kojoj se obavlja online trgovina. Višestruki odabir odgovora na ovo pitanje prikazan je na Grafikonu 1.

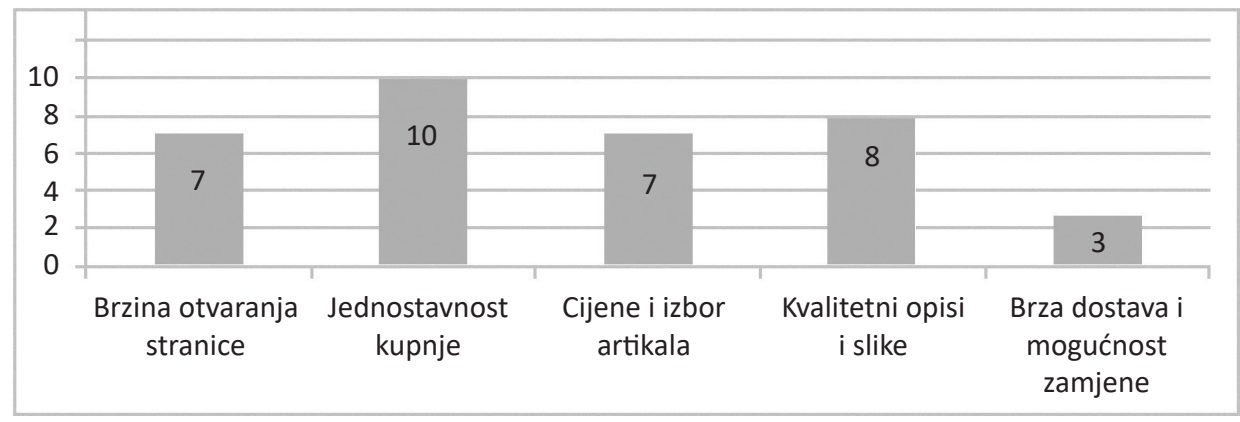

Grafikon 2. Oblik internetskog marketinga u koji poduzeće najviše ulaže (Izvor: istraživanje)

Nadalje, od ispitanih stručnjaka samo je jedan odgovorio da do sada nije bio upoznat s pojmovima optimizacije za tražilice i plaćenim oglasima. Taj se rezultat može smatrati pozitivnim s obzirom da je u uzorku bilo i poduzeća koja se ne bave direktno digitalnim marketingom već su samo prisutni u online okruženju. Na pitanje o prosječnoj cijeni oglasa po kliku koji plaćaju u Republici Hrvatskoj, ukoliko koriste plaćene oglase, dobiveni su odgovori koji se prikazuju na Grafikonu 3. Iz grafikona je vidljivo kako samo dva poduzeća izdvajaju između 20 i 50 lipa po kliku za određeni oglas. Jednak broj poduzeća izdvaja između 5 do 10 lipa te između 10 do 20 lipa za prikazani oglas po kliku. Radi se uglavnom o onoj najkorištenijoj tražilici - Google tražilici. 


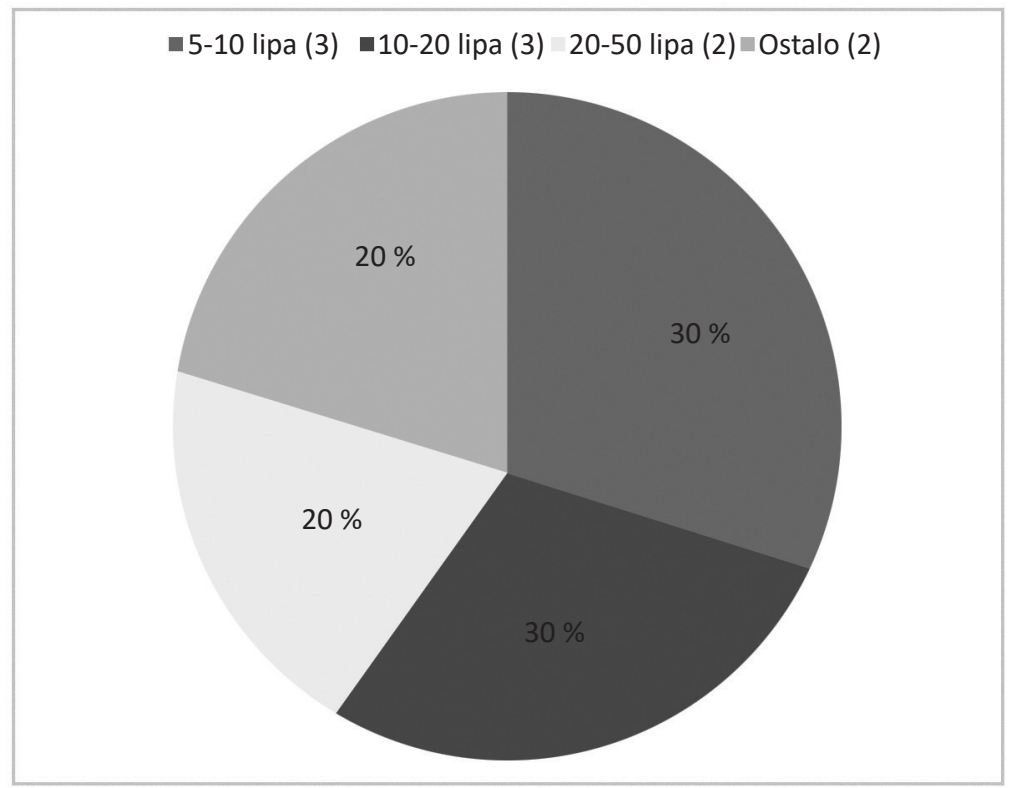

Grafikon 3. Prosječna cijena po kliku za Google Adwords-e (Izvor: istraživanje)

U nastavku je postavljeno pitanje vezano za način provođenja optimizacije. Šest promatranih poduzeća iz uzorka odgovorilo je kako samostalno optimizira svoju web stranicu dok poduzeća koja su manja (njih 4) koriste vanjske suradnike. Razlog angažiranja vanjskih suradnika je nedostatak potrebe za zapošljavanjem dodatnog radnika koji će raditi na optimizaciji web stranice.

Sljedeće pitanje odnosilo se na postotak povećanja kupovine koju je, prema procjenama stručnjaka, uzrokovala optimizacija web stranica. Odgovori su prikazani na Grafikonu 4. Iz grafikona je vidljivo da se kod četiri poduzeća tek 5-10\% kupovine može pripisati provedenoj optimizaciji web stranice, dok su stručnjaci iz pet poduzeća odgovorili da se radi o 10 do 30\% kupovine. Navođenje manjeg postotka kupovine može se opravdati neimanjem i nekorištenjem online prodaje. Jedno poduzeće navodi kako se više od $50 \%$ kupovine odvija zbog optimizacije, a razlog je trenutna zdravstvena situacija u Republici Hrvatskoj i svijetu. 
Također, važno je navesti kako ovo poduzeće prodaje putem interneta te im je SEO optimizacija od velike važnosti.

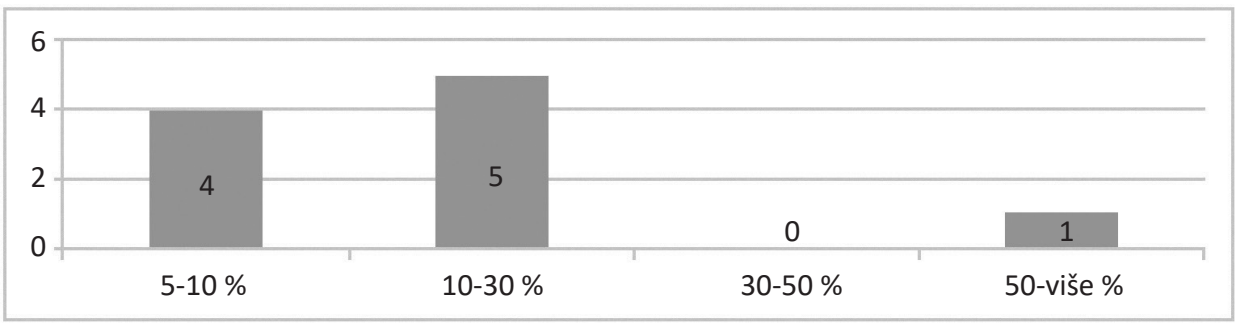

Grafikon 4. Postotak kupovine koji se odvija zbog SEO optimizacije

(Izvor: istraživanje)

U nastavku se istraživanje bavi dijelovima i tipovima optimizacije. Stručnjaci iz osam promatranih poduzeća izjavljuju kako je najvažnije u kombinaciji koristiti sva tri dijela optimizacije web stranice za tražilice, dakle on-page optimizaciju, off-page optimizaciju te tehničku optimizaciju. Grafikon 5 prikazuje višestruki odabir odgovora na pitanje „Koje faktore on-page optimizacije smatrate najvažnijima?" Vidljivo je kako čak osam poduzeća smatra da je najvažniji faktor on-page optimizacije sadržaj stranice. Odgovori su razumljivi s obzirom da bez kvalitetnog i bogatog sadržaja poduzeće ne može efikasno konkurirati na tržištu. Sljedeći važan faktor je brzina otvaranja / učitavanja web stranice. Ako stranici učitavanje dugo traje kupac će najvjerojatnije otići na konkurentnu web stranicu. Nadalje, samo su dva poduzeća odgovorila kako je struktura web stranice važan faktor kod on-page optimizacije.

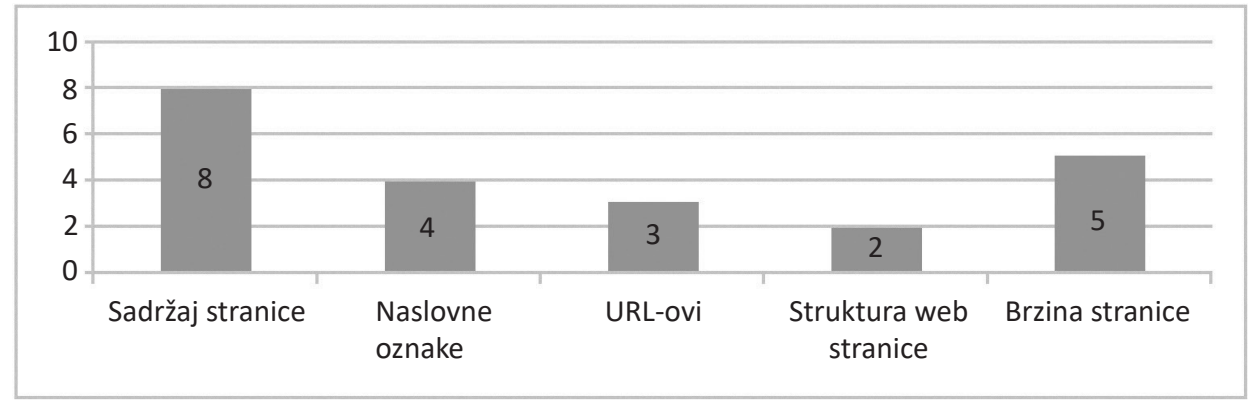

Grafikon 5. Relevantni faktori on-page optimizacije za tražilice (Izvor: istraživanje) 
Kada su stručnjaci upitani jesu li čuli za pojmove white hat i black hat optimizaciju samo je jedan (onaj koji nije upoznat niti s pojmom optimizacije) odgovorio kako nije čuo za te pojmove, dok su se ostali izjasnili pozitivno. Devetero stručnjaka odgovara kako redovito koriste white hat optimizaciju. Osam poduzeća / stručnjaka izjavljuje kako nikada nisu koristili black hat tip optimizacije međutim, jedan stručnjak navodi kako ga je njegovo poduzeće koristilo. Jedno poduzeće (koje niti ne koristi optimizaciju) ne koristi niti jedan od navedenih oblika optimizacije.

Istraživanjem se nastojala obuhvatiti i vrsta alata koji se koriste kod optimizacije web stranica te su stručnjaci pitani koje alate najviše koriste (mogućnost višestrukog odabira odgovora). Njihovi odgovori su vidljivi na Grafikonu 6. Prema dobivenim rezultatima najviše poduzeća koristi Google Analytics, što ne čudi budući da je Google najčešće korištena tražilica, a njegovi alati obuhvaćaju veliko područje koje služi za praćenje optimizacije. Dva poduzeća su odgovorila da koriste Keyword Planner, Search Cosolu te Google Data Studio. Budući da ostali alati nisu toliko poznati ne iznenađuje činjenica da ih poduzeća iz uzorka ne koriste. Pretpostavka je da će s vremenom njihovo (i raznih drugih) korištenje, sukladno razvoju i prilagodbi marketinških strategija promjenama u okruženju, rasti.

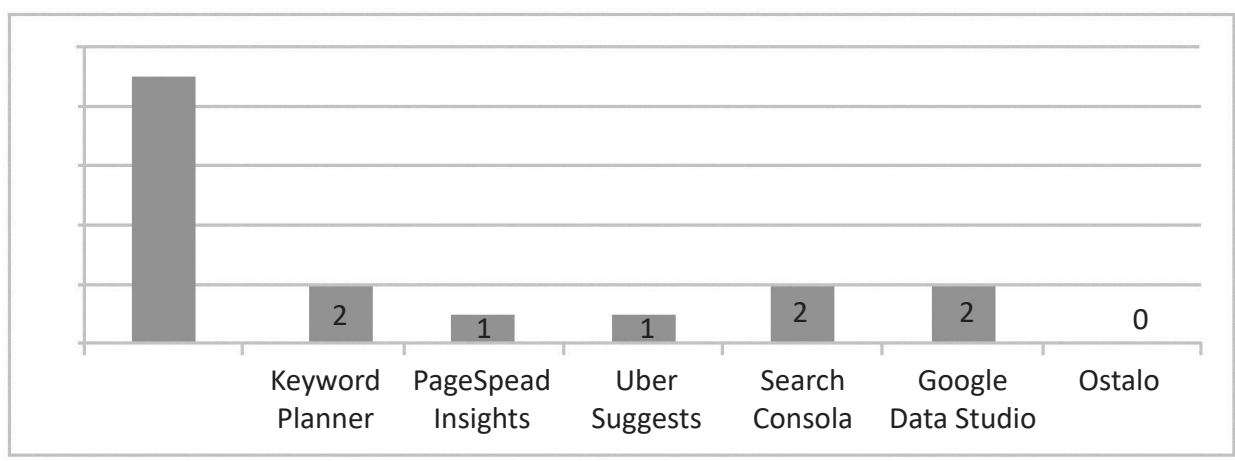

Grafikon 6. Najkorišteniji SEO alati

(Izvor: istraživanje) 
Nadalje, devet od deset poduzeća odgovorilo je kako vode korporativne blogove i kroz njih objavljuju vijesti na svojim web stranicama. Jedno poduzeće posjeduje web stranicu tek 4 mjeseca te još nije spremno za vođenja korporativnog bloga, dok ostala poduzeća koja posluju dugi niz godina redovito koriste blog kao oblik komunikacije sa svojim korisnicima. Smatraju da će redovita komunikacija s korisnicima / kupcima putem bloga omogućiti i zadržavanje visoke pozicije na tražilicama. Kada su upitani koliko često objavljuju novosti kroz korporativne blogove, najviše poduzeća je odgovorilo da objavljuju novosti od 3 do 5 puta mjesečno. Taj je podatak pozitivan jer tako poduzeće osigurava ažurne podatke, informacije i novosti korisnicima što s druge strane, povećava promet prema web stranici te osigurava visoku poziciju na tražilicama. Jedno od važnijih pitanja koje se postavilo stručnjacima bilo je „Koliko vremena mjesečno izdvajate za SEO optimizaciju?" Prema rezultatima šest poduzeća za optimizaciju izdvaja do pet sati mjesečno, a četiri poduzeća izdvajaju i do 10 sati mjesečno. Može se zaključiti kako će se broj sati uloženih u optimizaciju stranice povećavati usporedno s rastom poduzeća, ali i s ulaganjem u aktivnosti digitalnog marketinga.

Sljedeće pitanje je bilo vezano za recenzije i komentare koje je moguće ostaviti od strane korisnika na njihovim stranicama. Na tvrdnju „Mogućnost ostavljanja recenzija i komentara na stranici je korisna za napredak poduzeća“ ispitanici su pružili neutralni odgovor (srednja ocjena 2,5) na petostupanjskoj Likertovoj skali (1 u potpunosti se ne slažem - 5 u potpunosti se slažem). Rezultat donekle iznenađuje jer je za poduzeća korisno da znaju i dobre i loše strane poslovanja kako bi ga mogli poboljšavati, a time i zadržati klijente. Kod slaganja / neslaganja s tvrdnjom „Blogovi na web stranici su korisni za kupce“ poduzeća su također neutralna (srednja ocjena 2,8). Ovdje se postavlja pitanje imaju li poduzeća uopće uvid ili povratnu informaciju o čitanosti vlastitih blogova, što svakako treba biti predmetom idućih istraživanja. Nadalje, istraživanjem se željelo saznati mišljenje ispitanika o korisnosti „People also ask“ tablica kod rezultata pretraživanja. Sedam stručnjaka se izjasnilo da je ona vrlo korisna, dok ostali smatraju kako im je ta tablica nebitna.

Stručnjacima je također postavljeno pitanje ima li njihovo poduzeće profil na Google My Business. Šestero se izjasnilo da njihova poduzeća imaju taj profil, i smatra ga vrlo korisnim za poslovanje, ali i za optimizaciju stranice. No, promatrajući lokalno pretraživanje, koje je važan dio aktivnosti Google My Business, na tvrdnju „Lokalno pretraživanje je vrlo korisno te se u našem poduzeću prema statistikama bilježi rast pretraživanja na lokalnoj razini“ ispitanici su neodlučni (srednja ocjena 2,6). Prema rezultatu njihovog slaganja s navedenom tvrdnjom vidljivo je da nisu sigurni u vezi uloge lokalnog pretraživanja, ali ga koriste uslijed prisutne svjesnosti o korisnosti prilikom optimizacije i rangiranja na tražilicama. 
Posljednje pitanje u sklopu istraživanja provedenog na poduzećima u sjevernoj Hrvatskoj vezano je uz njihovo promišljanje oko budućnosti online trgovine i potpune zamjene klasične trgovine online trgovinom. Šest ispitanika je odgovorilo kako bi moglo doći do tog scenarija, dok se ostala četiri poduzeća ne slažu s time. $S$ jedne strane, ovakvi odgovori su i razumljivi s obzirom na strukturu uzorka, tj. prisutnost poduzeća koja ne posluju online.

Kao zaključak ovog istraživanja navodi se kako, iako se radi o malom uzorku poduzeća, postoji pozitivna percepcija uloge optimizacije web mjesta u poslovanju. Prepoznat je značaj ovog oblika internetskog marketinga u postizanju veće efikasnosti poslovanja u online okruženju. lako optimizacija za tražilice kao promotivni alat egzistira i primjenjuje se u praksi već duže vrijeme uočeno je da poduzeća još uvijek nisu dovoljno upućena u sve njezine mogućnosti, te da je ne koriste na odgovarajući način.

\section{ZAKLJUČAK I OGRANIČENJA}

Ovaj rad pruža teorijski koncept optimizacije web stranice poduzeća s fokusom na dijelove, tipove i sam proces optimizacije kao i njezin utjecaj na online trgovanje. Cilj teorijskog koncepta je dobivanje temeljnih znanja o predmetnoj temi i bolje razumijevanje rezultata provedenog empirijskog istraživanja. Temeljem dobivenih rezultata zaključuje se kako mikro i mala poduzeća na području sjeverne Hrvatske pozitivno percipiraju značaj postojanja korporativne web stranice, a time i sve postupke u okviru internetskog marketinga koji vode uspješnijoj promociji poduzeća. Predmet istraživanja u ovom radu je optimizacija za web tražilice i utvrđivanje razine svjesnosti poduzeća o njezinom značaju i primjeni.

Sve većim utjecajem i primjenom digitalnih tehnologija poslovanje poduzeća prelazi u digitalno okruženje. Uz klasične oblike trgovanja trgovina poduzeća uvode online prodaju ili se orijentiraju u potpunosti na online prodaju. Vrlo konkurentno okruženje zahtijeva diferencijaciju i pozicioniranje web trgovina. U postizanju tog cilja pomaže optimizacija web stranica čiji je zadatak postići veću prepoznatljivost među tražilicama. Za razliku od plaćenog oblika promocije gdje se stranica prikazuje na tražilici prilikom ukucavanja ključne riječi optimizacija je besplatna. Temeljem analize različitih elemenata algoritmi tražilice web stranicu rangiraju i prikazuju u rezultatima pretraživanja. Cilj je da to bude na prvoj strani prikaza što je moguće više. Kako bi web stranica taj rang ostvarila nužna je njezina optimizacija prema pravilima koje postavljaju tražilice.

Prema dobivenim rezultatima poduzeća su upoznata s pojmom optimizacije i znaju koja je njezina svrha. Poduzeća su zainteresirana da prikaz njihovih stranica 
bude što višeg ranga znajući da to vodi generiranju većeg broja posjeta. Veća poduzeća za optimizaciju koriste vanjske tvrtke dok ju manja provode sama. Sve veći pritisak novih tehnologija sasvim sigurno tražit će i veće prilagodbe novim načinima i kanalima komunikacije i prodaje. Stavovi i razmišljanja poduzeća o optimizaciji iznesena u ovom radu idu u tom smjeru. Osnovno ograničenje istraživanja odnosi se na broj poduzeća koja su se odazvala anketiranju tako da bi se buduća istraživanja trebala fokusirati odnosno obuhvatiti veći uzorak. S druge strane, smatra se da bi bilo korisno istražiti i percepciju samih internet korisnika u svezi korisnosti optimizacija i njezinog utjecaja na njih. Temeljem analize sekundarnih i primarnih izvora podataka može se zaključiti kako ovo područje internetskog marketinga još uvijek nije dovoljno istraženo, te ima velikog potencijala za daljnji rast u Hrvatskoj i u svijetu.

\section{LITERATURA}

1/ Ron BERMAN, Zsolt KATONA, "The Role of Search Engine Optimization in Search Marketing", Marketing Science, 2013., Vol. 32, No. 4, 644-651.

2/ Chen-Yuan CHEN, Bih-Yaw SHIH, Zih-Siang CHEN, Tsung-Hao CHEN, „The exploration of internet marketing strategy by search engine optimization: $\mathrm{A}$ critical review and comparison", African Journal of Business Management, 2011., Vol. 5, No. 12, 4644-4649.

3/ Eric ENGE, Stephan SPENCER, Rand FISHKIN, Jessie.C. STRICCHIOLA, „The Art of SEO: Mastering Search Engine Optimization“ (1st edition), O'Reilly Media, Inc., Sebastopol, 2009.

4/ Karla GAŠPARIĆ, „Uloga optimizacije u online trgovanju“ - diplomski rad, Fakultet organizacije i informatike, Varaždin, rujan 2020.

5/ https://digitalcircleweb.com/seo-zurnal/seo-strategije-black-hat-white-hatgray-hat-i-asshat/ (preuzeto 08.06.2020.)

6/ https://kuhada.com/blog-novosti-i-najave/47-vijesti/341-razlika-izmedju-sem-i-seo.html (preuzeto 27.05.2020.)

7/ https://marker.hr/blog/kako-povecati-prodaju-putem-ppc-oglasa-149/(preuzeto 02.06.2020.)

8/ https://moz.com/learn/seo/on-page-factors (preuzeto 02.06.2020.)

9/ https://neomedia.hr/napredna-optimizacija-za-trazilice-on-page-seo/ (preuzeto 02.06.2020.)

10/ https://neomedia.hr/napredna-optimizacija-za-trazilice-tehnicki-seo (preuzeto 03.06.2020.) 
11/ https://tilio.hr/google-adwords-oglasi/ (preuzeto 10.06.2020.)

12/ https://www.jasnoiglasno.com/sto-je-seo-i-zasto-je-bitan-3938/(preuzeto 01.06.2020.)

13/ http://www.webtech.com.hr/seo.php (preuzeto 08. 06. 2020.)

14/ Ayush JAIN, ,"The Role and Importance of Search Engine and Search Engine Optimization", International Journal of Emerging Trends and Technology in Computer Science, 2013., Vol. 2, No. 3, 99-102.

15/ Aleksandra KRAJNOVIĆ, Dominik SIKIRIĆ, Monika HORDOV, „Digitalni marketing - nova era tržišne komunikacije", Sveučilište u Zadru, Zadar, 2019.

16/ W. T. KRITZINGER, M. WEIDEMAN, "Search Engine Optimization and PeyPer-Click Marketing Strategies", Journal of Organizational Computing and Electornic Commerce, 2013., Vol. 23, 273-286.

17/ Jerry L. LEDFORD, „Search Engine Optimization Bible“ (2nd edition), Wiley Publishing, Inc. Indianapolis, 2008.

18/ Ross A. MALAGA, „Search Engine Optimization-Black and White Hat Approaches", Advances in Computers, 2010., Vol. 78., 1-39.

19/ Jai MANRAL, Mohammed Alamgir HOSSAIN, „An Inovative Approach for online Meta Search Engine Optimization", The 6th Conference on Software, Knowledge, Information Management Application, Chengdu, China, 2012., 1-7.

20/ Mayank Kumar MITTAL, Neha KIRAR, Jasraj MEENA, „Implementation of search engine optimization - Through white hat techniques", International Conference on Advances in Computing, Communication Control and Networking, 2018., 674-678.

21/ Vikas M. PATIL, Amruta V. PATIL, „SEO: On-Page + Off-Page Analysis“, International Conference on Information, Communication, Engineering and Technology (ICICET), Zeal College of Engineering and Research, Narhe, Pune, India, 2018., 1-3.

22/ Ghulam Ali RAHU, Mansoor Hyder DEPAR, Sher Muhammad DAUDPOTO, Mir Sajjad Hussain TALPUR, Muhammad Malook RIND, Gordhan DAS, „Extending off-page search engine optimization (SEO) techniques based od google SEO techniques model“, Sci.Int. (Lahore), 2016., Vol. 28, No. 5, 4377-4384.

23/ Jakub ZILINCAN, "Search engine optimization“, CBU International Conference of Innovation, Technology Transfer and Education, 2015., 506-510. 


\section{SUMMARY}

\section{USAGE OF OPTIMIZATION IN ONLINE TRADING - EXAMPLE OF COMPANIES IN NORTHERN CROATIA}

In the earlier stages of its creation, the Internet was used for specific purposes such as the exchange of information within large companies or government institutions. By expanding the availability to end users, the amount of information that could be found on the Internet also increased. In order for users to be able to quickly and easily find relevant information for them, they use search engines. By using search engines, website owners prioritize search engine optimization, which is the focus of this paper.

By collecting secondary data, the theoretical basis of the concept and role of optimization was created, as well as the basic parts and types of optimization. As part of the empirical research, a survey questionnaire was created with the help of which a quantitative research was conducted on micro and small companies in northern Croatia. The questionnaire was sent to the e-mail of experts (digital marketing or marketing experts in general) of 52 companies, of which 10 experts fully answered all questions and their answers were subjected to statistical analysis presented in the paper. The aim of this paper was to get acquainted with the level of use of optimization by companies operating in the northern Croatia, including familiarity with the concept of optimization.

Based on the obtained results, it can be concluded that companies are mostly familiar with the concept of optimization, which is used in their companies. However, although they use a number of factors that are important for increasing search engine rankings, yet the awareness of the benefits and role of optimization in business is still not fully formed.

Key Words: digital marketing; online trading; SEM; PPC; SEO; SEO; Northern Croatia. 